\title{
Biological cyanide degradation in aerobic fluidized bed reactors: treatment of almond seed wastewater
}

\author{
S. Petrozzi, I. J. Dunn
}

Abstract The continuous aerobic transformation of synthetic cyanide waste-water, amygdalin solutions and almond seed extract containing cyanide was investigated in several fluidized bed reactors. Various inocula consisting of activated sludge or soil slurry were used. Successful inoculation was achieved with simple soil slurry. No significant influence was found between the performance of the systems inoculated with a cyanide contaminated soil and a garden soil. The performance and stability of the reactors with respect to degradation rate were tested for a range of cyanide loading conditions, with feed containing only cyanide, and with different additional carbon sources, as well as various $\mathrm{C}: \mathrm{N}$ ratios at a hydraulic retention time of $24 \mathrm{~h}$. No growth with cyanide as the sole source of carbon and nitrogen was observed. The system with lactate as the organic C-source was capable of operating at cyanide concentrations of $160 \mathrm{ppm}$ cyanide with a conversion rate of $0.125 \mathrm{~kg}$ cyanide $/ \mathrm{m}^{3} \mathrm{~d}$. Ammonia was the end product and the effluent concentration was $0.5 \mathrm{ppm} \mathrm{CN}^{-}$. The systems with ethanol as the organic C-source could degrade only $0.05 \mathrm{~kg}$ cyanide $/ \mathrm{m}^{3} \mathrm{~d}$, whose feed concentration was $60 \mathrm{ppm}$ cyanide. Amygdalin, an organic cyanide-containing compound present in stone fruit seeds, was fed as a model substrate. Degradation rates up to $1.2 \mathrm{~kg} \mathrm{COD} / \mathrm{m}^{3} \mathrm{~d}$ could be measured with no free or organically bound cyanide in the effluent. These rates were limited by oxygen transfer, owing to the large amount of degradable COD. The further investigations with almond seed extracts, confirmed the applicability of the aerobic process to treat food-processing waste streams having low concentrations of cyanide with high COD content.

\section{1}

\section{Introduction}

Cyanide is one of nature's most toxic substances. The fatal doses for human adults are $1-3 \mathrm{mg} / \mathrm{kg}$ body weight if indigested, $100-300 \mathrm{ppm}$ if inhaled, and $100 \mathrm{mg} / \mathrm{kg}$ body weight if adsorbed [1]. At normal $\mathrm{pH}$ and temperature, $\mathrm{CN}^{-}$is toxic to most species in freshwater or marine environments at a level of $0.1 \mathrm{ppm}$. Cyanide toxicity is essentially based on an inhibition of the oxygen-transport metabolism.

Received 30 June 1993

\section{S. Petrozzi, I. J. Dunn}

Biological Reaction Engineering Group, Chemical Engineering Department, ETH, 8092 Zurich, Switzerland

The authors wish to thank Dr. Ö.M. Kut for useful discussions.
Various processes such as metal finishing, photographic bleaching and galvanic industry produce substantial amount of wastewater, which may contain up to $70 \mathrm{~g} / \mathrm{l}$ of free cyanide and could have a high content of metal $(50 \mathrm{~g} / \mathrm{l})$. Unexpectedly, effluents of food and feed production can also contain cyanide. For example in Northern Europe bitter almonds are used to make marzipan and they contain amygdalin, a cyanogenic glycoside. Cyano-glycosides yield glucose, benzaldehyde and hydrocyanic acid when hydrolyzed in vitro by mineral acids or in vivo by enzymes. The name amygdalin ( $d$-mandelonitrile$\beta-d$-glucosido- $6-\beta-d$-glucoside) is currently used interchangeable with laetrile and is a cyanogenic glycoside which occurs in seeds; principally in bitter almonds, but also in peaches and apricots. Prunasin ( $d$-mandelonitrile glucoside) is reported to be the first enzymatic breakdown product of amygdalin (mol wt 457.42; C 52.51\%, H 5, 95\%, N 3.06\%, O 38.47\%), mandelonitrile being formed upon the hydrolysis of prunasin. Further products are glucose, benzaldehyde and hydrocyanic acid.

Chemical oxidation by strong oxidants, such as chlorine and hypochlorite, is the current cyanide removal technology for industrial wastewaters with high levels of cyanide. In the case of food industry effluents, which contain low concentrations of cyanide in a large volume of wastewater, the biological treatment could be a valid and cheaper alternative to the common chemical method. The biological detoxification would not be applicable to the high toxic wastewaters because of the lethal combination of high cyanide and high metal concentrations contained in the wastewater, that would render bacterial degradation impossible. The regulatory aspects of wastewater varies slightly from country to country in the range of $0.1-0.5 \mathrm{ppm}$ free cyanide. Despite its toxicity, many microorganisms have developed cyanide resistant respiratory systems to enable them to metabolize cyanide as source of nitrogen. Various microorganisms can produce (cyanogenesis) or degrade cyanide [2]. Cyanide can potentially be used as a source of carbon or nitrogen by specially selected organisms.

Biological conversion of cyanide to formamide and ammonia has been demonstrated in fungi [3] according to the reaction:

$\mathrm{HCN}+\mathrm{H}_{2} \mathrm{O} \rightarrow \mathrm{HCONH}_{2}$

$\mathrm{HCONH}_{2}+\mathrm{H}_{2} \mathrm{O} \rightarrow \mathrm{HCOO}^{-}+\mathrm{NH}_{4}^{+}$.

The experiments done by Basheer et al. [4] indicate that the cyanide decomposition by the immobilized enzyme CYANIDASE $^{\circledR}$ (NOVO Industri A/S) is a one step process:

$\mathrm{HCN}+2 \mathrm{H}_{2} \mathrm{O} \rightarrow \mathrm{HCOO}^{-}+\mathrm{NH}_{4}^{+}$. 
The microbial oxidation of cyanide by aerobic autotrophs may be given by:

Ammonification: $\mathrm{HCN}+0.5 \mathrm{O}_{2}+2 \mathrm{H}_{2} \mathrm{O} \rightarrow \mathrm{HCO}_{3}^{-}+\mathrm{NH}_{4}^{+}$.

Nitrification: $2 \mathrm{NH}_{4}^{+}+3 \mathrm{O}_{2} \rightarrow 2 \mathrm{NO}_{2}^{-}+4 \mathrm{H}^{+}+\mathrm{H}_{2} \mathrm{O}$

$2 \mathrm{NO}_{2}^{-}+\mathrm{O}_{2} \rightarrow 2 \mathrm{NO}_{3}^{-}$.

One means of microorganism selection is through continuous operation of a chemostat [5]. Since the specialist organisms almost always grow slowly, care must be taken in maintaining the dilution rate low enough that the organisms are not washed out. As a better alternative fluidized beds could advantageously be used for selecting organisms for cyanide degradation but this technique has seldom been practiced. Fluidized beds are an accepted technology for contacting a continuous fluid phase with a discontinuous particulate solid phase. Particles which are covered with a biofilm are lighter than clean particles and are therefore suspended at lower velocities. Fluidized beds exhibit a natural stratification with the less dense particles collecting at the top of the bed and the denser particles at the bottom. This separation is convenient for removing biomass and for controlling the biomass film thickness, for minimizing mass transfer resistances.

The literature indicates that cyanide and thiocyanate are effectively oxidized with a suitably acclimated activated sludge system [6], using a two stage denitrifying/nitrifying suspended culture. The synthetic phenol, cresol, $\mathrm{CN}^{-}$and $\mathrm{SCN}^{-}$containing waste water was fed with varying $\mathrm{CN}^{-}$levels, residence times and sludge ages. The results showed that nitrification was influenced by $\mathrm{CN}^{-}$and that $\mathrm{CN}^{-}$removal was promoted by higher sludge age.

In one reported study, coke plant waste water containing $2.7 \mathrm{~g}$ COD/l, $510 \mathrm{ppm}$ phenols, $75 \mathrm{ppm}$ ammonia, $10 \mathrm{ppm}$ cyanide and $340 \mathrm{ppm}$ thiocyanate was acclimated to a two stage biofilm fluidized bed system, which included anaerobic dinitrification and aerobic nitrification reactors [7]. In this system about $65 \%$ of the carbon served as electron donor for the nitrates and was oxidized in the denitrification stage, thus reducing the required oxygen. Inhibition of the nitrate-forming step led to high nitrite concentrations. Total cyanide and thiocyanate removals varied according to the total residence time and were $42 \%$ and $99.5 \%$, respectively for $26 \mathrm{~h}$.

In a similar study [8] with the same reactors, a mixture of steel blast furnace scrubber water and coke plant water was degraded. In this study the presence of $7 \mathrm{ppm}$ of zinc appeared to influence the nitrification stage. This more dilute wastewater could be degraded almost completely in $4.5 \mathrm{~h}$ total residence time. Recently fixed bed columns have also been employed to degrade cyanide under anaerobic conditions [9].

The successful development of a biofilm for treating wastes requires proper inoculation procedures. Soil contains complex and numerous specialized groups of microorganisms that could be exploited for the inoculation of a bioreactor, emphasizing the importance of the interactions among mixed cultures. The purpose of the present work was to investigate the suitability of a fluidized bed reactor for the selection of a mixed culture from soil organisms for the aerobic degradation of cyanide in different kinds of waste waters. To compare between the natural ability of

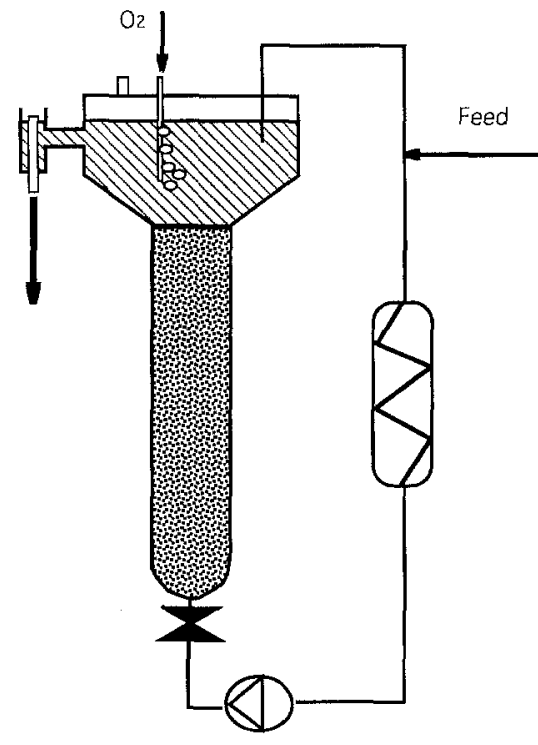

Fig. x. Schematic drawing of the continuous fluidized bed reactor

Table 1. Experimental reactor conditions

\begin{tabular}{ll}
\hline Temperature & $35^{\circ}-37^{\circ} \mathrm{C}$ \\
$\mathrm{pH}$ & $7.8-8$ \\
Reactor volume & 0.81 \\
Hydraulic residence time & $24 \mathrm{~h}$ \\
Inocula & Activated sludge or \\
& soil slurry \\
\hline
\end{tabular}

native micropopulation and adapted microbial cultures, an active culture from another plant, to degrade cyanide and the influence of added carbon sources, several parallel reactors were operated under different conditions.

\section{2}

\section{Materials and methods}

\section{1}

\section{Aerobic fluidized bed reactor AFBR}

The reactors consisted of standard glass parts fitted together with tapered joints as shown in Fig. 1. The reactor columns were approximately 0.81 volume, with a height of $34 \mathrm{~cm}$ and an internal diameter of $3 \mathrm{~cm}$. The conical upper settling zones were specially built and had a diameter of $10 \mathrm{~cm}$. Each reactor contained initially $70 \mathrm{ml}$ settled volume of quartz sand. The upflow velocity rate through the column was adjusted to achieve an expansion between 200 and $250 \%(100 \%=$ height of the settled carrier). Circulation and fluidization flow rates were maintained with a peristaltic pump using Marprene tubing. The feed was introduced into the system on the suction side of the recycle pump, using a multi-channel peristaltic pump. The reactor was fed continuously, and the effluent exited through an overflow. The reactor was thermostated by passing the recycled liquid through a heat exchanger. The $\mathrm{pH}$ was not controlled. The aeration was provided with pure oxygen in order to minimize the gas flow rate and stripping of HCN. The oxygen was sparged from the top directly in the reactor. The range of the gas flow rates was between 10 and $50 \mathrm{ml} \mathrm{O}_{2} / \mathrm{min}$ and the dissolved oxygen 
varied from 1-14 $\mathrm{mg} \mathrm{O}_{2} / 1$ depending on the activity of the reactor. The reactors were housed in a ventilation hood to minimize the potential hazard associated with cyanide. The experimental reactor conditions are shown in Table 1.

\section{2}

\section{Experimental methods}

\subsection{1}

\section{Analytical methods}

Reduction of chemical oxygen demand (COD) and disappearance of the substrate were used for the evaluation of the reactor's degradation performance. Influent and effluent samples were filtered through hydrophobic $0.45 \mu \mathrm{m}$ filters (Minisart NML Sartorius). Routine quantitative analysis of lactate, ethanol, phenol, ammonia, nitrate, nitrite and cyanide were made using commercial colorimeter test systems (Nanocolor ${ }^{\circledR}$ ). Only free cyanide and simple cyanides which can be decomposed by chlorine are detected with this assay. Formamide was measured using a spectrophotometric method [3], but was not detected. The $\mathrm{pH}$ measurements were made using a gel electrode (Ingold). Dissolved oxygen (DO) was monitored with an electrode (WTW). The routine off-gas cyanide concentration were determined with Dräger ${ }^{\circledR}$ diffusion tubes. This method agreed with the spectrophotometric determination after absorbing the cyanide in a gas washer containing $0.1 \mathrm{~N} \mathrm{NaOH}$. The alkaline solution was neutralized prior to the analysis with $0.1 \mathrm{~N} \mathrm{HCl}$. Amygdalin content was estimated by ultraviolet (UV) absorbance. The bacterial concentration was measured as cell dry weight. A known volume of the liquid phase of the reactor was filtered through a $0.45 \mu \mathrm{m}$ filter and dried at $110^{\circ}$ until a constant weight was reached.

\subsection{2}

\section{Organically bound cyanide}

The bound cyanide contained in cyanide-yielding organic compounds was determined after hydrolysis; the acidified sample was stripped with air for $30 \mathrm{~min}$ and successively heated in sealed glass tubes at $110^{\circ}$ with $20 \%(\mathrm{w} / \mathrm{w})$ conc. $\mathrm{HCl}$ for $3 \mathrm{~h}$. After adjusting the $\mathrm{pH}$ to 8 , the organically bound cyanide was analyzed as free cyanide.

\subsection{3}

\section{Synthetic waste water}

The feed consisted of synthetic potassium cyanide solutions supplemented by either sodium lactate, phenol or ethanol in deionized water. In addition nutrients salts were added in the following amounts: $0.4 \mathrm{mg} / \mathrm{CaCl} ; 1.8 \mathrm{mg} / \mathrm{l} \mathrm{MgCl} .6 \mathrm{H}_{2} \mathrm{O}$; $1.3 \mathrm{mg} / \mathrm{l} \mathrm{CoCl}_{2} .6 \mathrm{H}_{2} \mathrm{O} ; 0.4 \mathrm{mg} / \mathrm{l} \mathrm{ZnSO}_{4} \cdot 7 \mathrm{H}_{2} \mathrm{O} ; 0.4 \mathrm{mg} / \mathrm{l}$ $\mathrm{NaMoO}_{4} \cdot 2 \mathrm{H}_{2} \mathrm{O} . \mathrm{KH}_{2} \mathrm{PO}_{4}$ buffer solution was also added ( $\mathrm{pH} 8$ ).

At the beginning of period IV the feed consisted of a synthetic amygdalin (Fluka) solution buffered and supplemented by nutrients salts. At the final part of this period the feed was a hot water extract of almond seeds.

\section{3}

\section{Results}

The disappearance of cyanide from the aqueous solution can be attributed to several reactions: Microbial transformation/

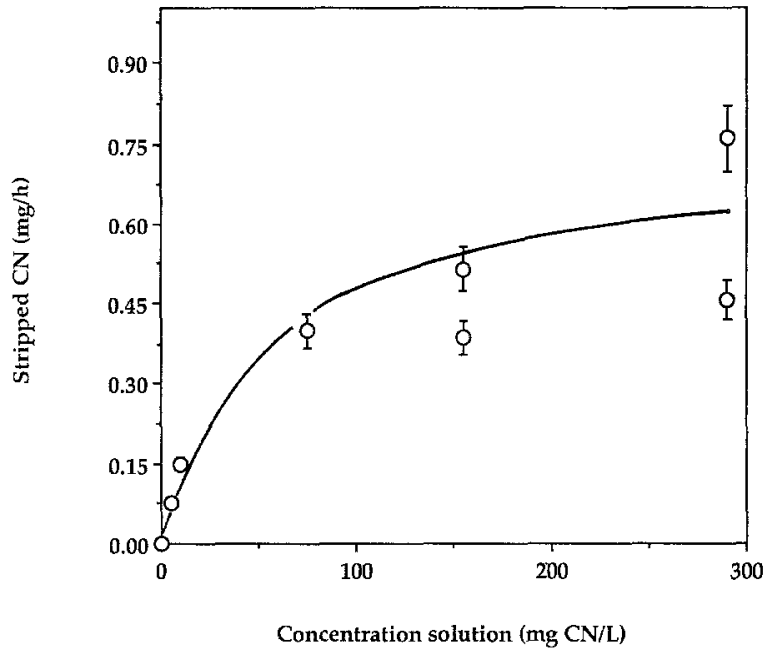

Fig. 2. Volatility of $\mathrm{CN}^{-}$in a $0.2 \mathrm{l}$ batch reactor at $\mathrm{pH} 8$ and $25^{\circ}$. Oxygen flow rate $=60 \mathrm{ml} / \mathrm{min}$

degradation, loss to the air, complex formation and adsorption. The volatilization of cyanide was investigated in a 0.21 batch reactor at $25^{\circ}$. The gas flowrate was $60 \mathrm{ml}$ oxygen/min and the potassium cyanide solution had a pH of 8 . After $24 \mathrm{~h}$ of gassing the solution, the difference in cyanide concentration was determined. The volatility was found to be favoured by high solution concentrations, as seen in Fig. 2. The stripping rate during biological treatment will always be very small, because of the very low cyanide concentrations of around two $\mathrm{ppm} \mathrm{CN}^{-}$ which must be maintained in the reactor.

\section{1}

\section{Period I}

\subsection{1}

\section{Startup procedure}

Preliminary experiments were carried out in order to select the most promising conditions for the main experiments. Cyanide degrading microorganisms were selected in continuously fed aerobic fluidized sand bed reactors. All the systems were started in the same way and run for an adaptation period of 30 days with a cyanide concentration of $15 \mathrm{ppm} \mathrm{CN}{ }^{-}$at the same conditions. The inoculum consisted of activated sludge obtained from the municipal wastewater treatment of Zürich/Werdhölzli. After the selection/adaption period, the treatment systems were operated at several $\mathrm{CN}^{-}$loading conditions in order to evaluate the performances of each reactor with external carbon source.

\subsection{2}

\section{Evaluation of additional C-source in media}

The principle elemental components of the cell ( $\mathrm{C}, \mathrm{N}, \mathrm{O}, \mathrm{H}, \mathrm{P}, \mathrm{S}$, $\mathrm{Mg}$ and $\mathrm{K}$ besides others) must be supplied in the medium for cells to grow. It is recognized that a number of factors determine the growth of an organism. One very important factor of the biological conversion of a compound, is the nature and the complexity of the medium like inhibitory effects, $\mathrm{C} / \mathrm{N}$ ratio etc. During period $\mathrm{I}$, three different additional carbon sources were used (Table 2). Only one reactor was started with cyanide as the sole carbon and sole nitrogen source $\left(\mathrm{R}_{4}\right)$, the others had phenol 
Table 2. Reactor feed parameters in period I

\begin{tabular}{llll}
\hline Reactor & $\begin{array}{l}\text { Additional C-source } \\
(\mathrm{mg} / \mathrm{l})\end{array}$ & $\begin{array}{l}\text { COD } \\
(\mathrm{mg} / \mathrm{l})\end{array}$ & $\begin{array}{l}\text { Carbon } \\
(\mathrm{mg} / \mathrm{l})\end{array}$ \\
\hline R1 & Phenol 100 & $\begin{array}{l}\text { Not } \\
\text { measured }\end{array}$ & $77+\mathrm{C}-\mathrm{CN}$ \\
R2 & Lactate 500 & 520 & $201+\mathrm{C}-\mathrm{CN}$ \\
R3 & Ethanol 400 & 850 & $208+\mathrm{C}-\mathrm{CN}$ \\
R4 & - & - & $0+\mathrm{C}-\mathrm{CN}$ \\
\hline
\end{tabular}

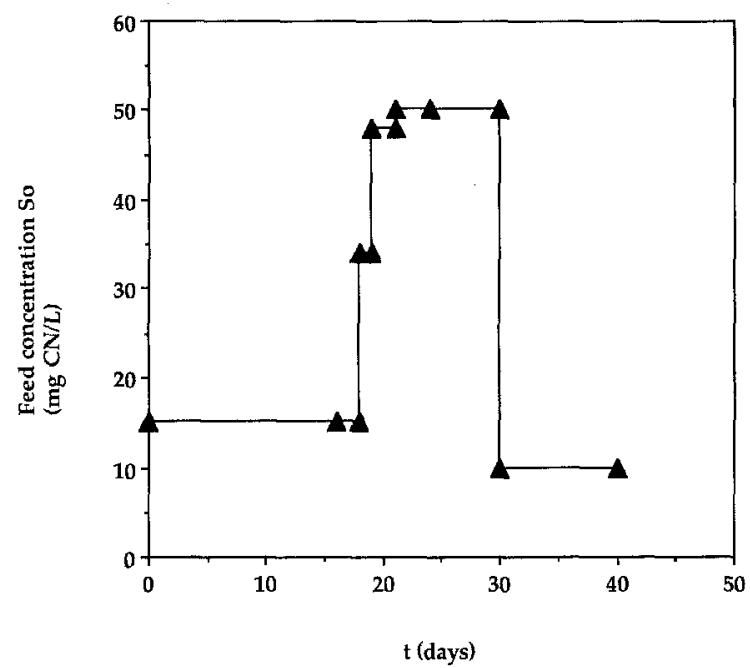

Fig. 3. Effluent concentration profile for period I

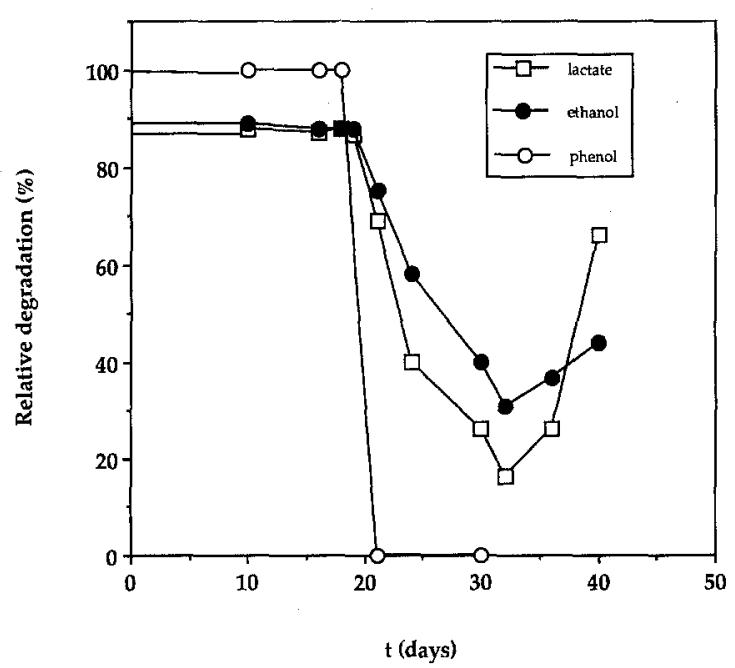

Fig. 4. Relative degradation rates during period I. $100 \%=500 \mathrm{ppm}$ lactate; $400 \mathrm{ppm}$ ethanol; $100 \mathrm{ppm}$ phenol

(R1), lactate (R2) or ethanol ( $\left.\mathrm{R}_{3}\right)$, respectively, as additional carbon source. In order to compare the performance of the four systems, the cyanide concentration in the feed was increased stepwise, while the carbon source, $200 \mathrm{ppm}$ carbon for the lactate and ethanol systems, was maintained at the same level as shown in Fig. 3. The responses of the reactors for the period I are

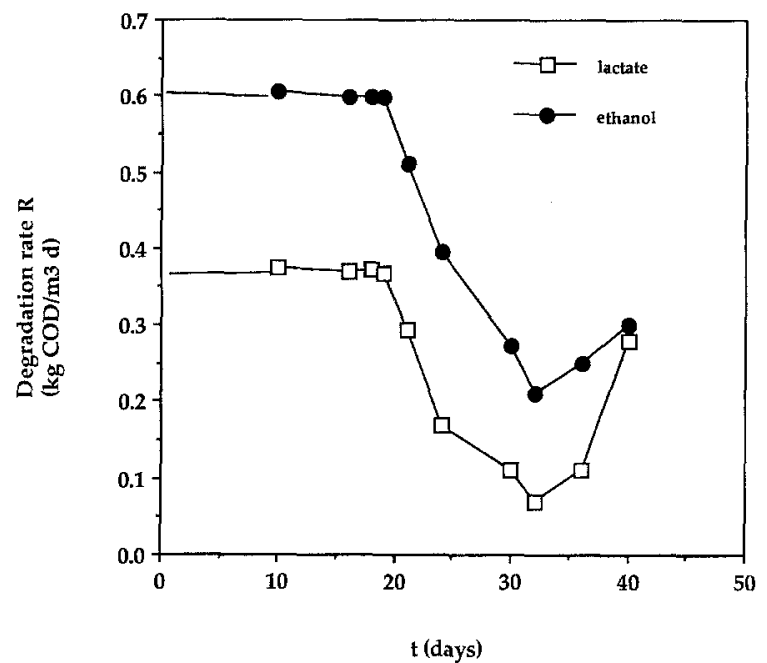

Fig. 5. COD degradation rates of the systems with lactate and ethanol during period I

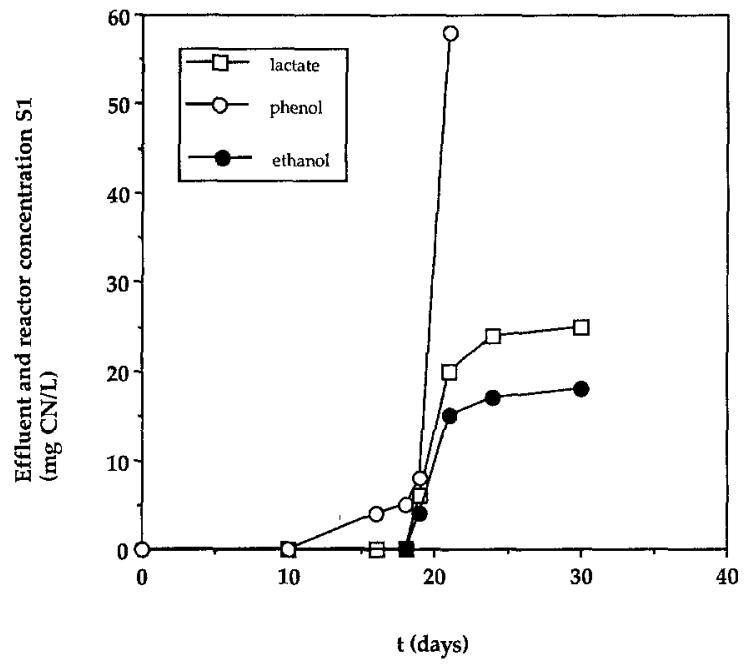

Fig. 6. Response of the reactor effluent concentrations during period I

given in Fig. 4 for the relative degradation rates and in Fig. 5 for the COD degradation rates. The systems with lactate and ethanol as the carbon source performed better than the system with phenol. The maximum toxic loading was started at day 21, which caused a decrease of the degradation rates for the lactate and for the ethanol systems. At the same time, the phenol system degradation rate dropped at zero. The cyanide influent concentration was reduced from $50 \mathrm{ppm} \mathrm{CN}^{-}$to $10 \mathrm{ppm} \mathrm{CN}^{-}$at the end of day 30. In Fig. 6 it is seen that the effluent cyanide concentrations were low for the ethanol and lactate system, while the phenol system had the highest concentrations. These concentration profiles are a result of the dynamic loading effects and the cyanide degradation rates. The recovery of the ethanol and lactate reactors began soon after switching the cyanide loading to $10 \mathrm{ppm} \mathrm{CN}^{-}$and proceeded more rapidly for the lactate system than for the ethanol system (compare Fig. 4 and Fig. 5), reaching a rate close to the original after 10 days. No recovery could be observed for the phenol system. A possible 
explanation is that phenol exerted an additional inhibitory effect. No cyanide disappearance was detected in the reactor with cyanide as the sole carbon source; it was apparently not utilized as a carbon source.

\section{2 \\ Period II}

\subsection{1}

\section{Cyanide degradation in continuous AFBR with soil microorganisms}

Lactate and ethanol were selected with preliminary experiments as the most promising supplementary carbon source. Three laboratory-scale fluidized bed reactors were used in parallel experiments. The time needed to start up biological degradation processes can be shortened by a proper choice of the inoculum. These procedures vary from the simple transferring of an active culture from a well operating plant, to the purchase of microbial mixtures or pure cultures that are commercially supplied in many countries. The inoculation with soil, as an environment for numerous active microorganisms, was exploited here. Two soil samples from deliberately selected location were used as inocula. The soil samples were collected on the surface at a maximum depth of $10 \mathrm{~cm}$ and were used without pretreatment. One soil sample was collected at a cyanide contaminated site by a chemical plant. The other soil sample was collected from an ETH garden. The two samples were treated identically. Two hundred grams of soil were placed in a $500 \mathrm{ml}$ Erlenmeyer and made into a slurry $(50 \%$ water: wt $/ \mathrm{wt})$. After adding nutrient agar, the Erlenmeyer flasks, sealed with Parafilm, were placed in a shaker at $37^{\circ}$ for $72 \mathrm{~h}$. After the shaking period, the soil suspensions were filtered through a coarse filter. A $200 \mathrm{ml}$ portion of the collected filtrate were transferred into each of the reactors as inocula.

The three new reactors were: The reactors $R E 1$ with ethanol and RL with lactate as the supplementary carbon source were inoculated with the contaminated soil. Reactor RE2 with ethanol as the supplementary carbon source was inoculated with "clean" soil slurry. The startup procedure was the same as in period I,

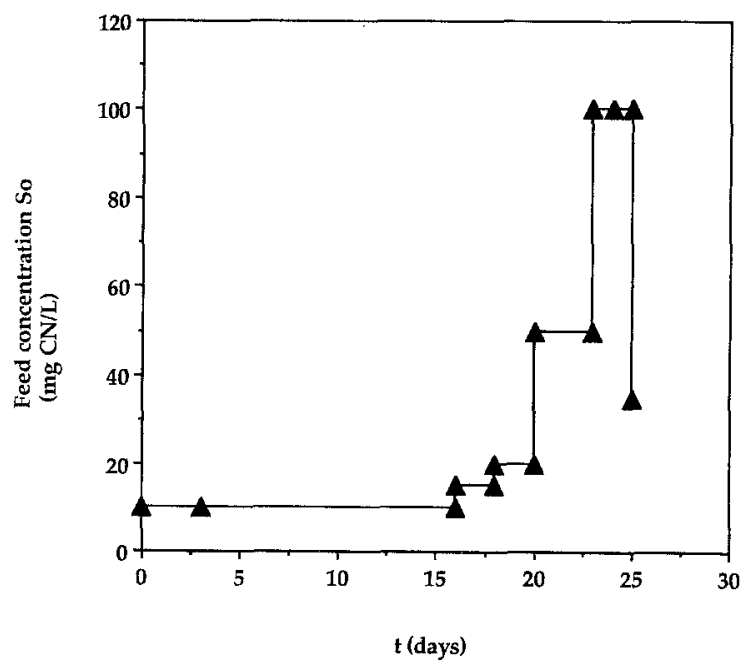

Fig. 7. Effluent concentration profile for period II

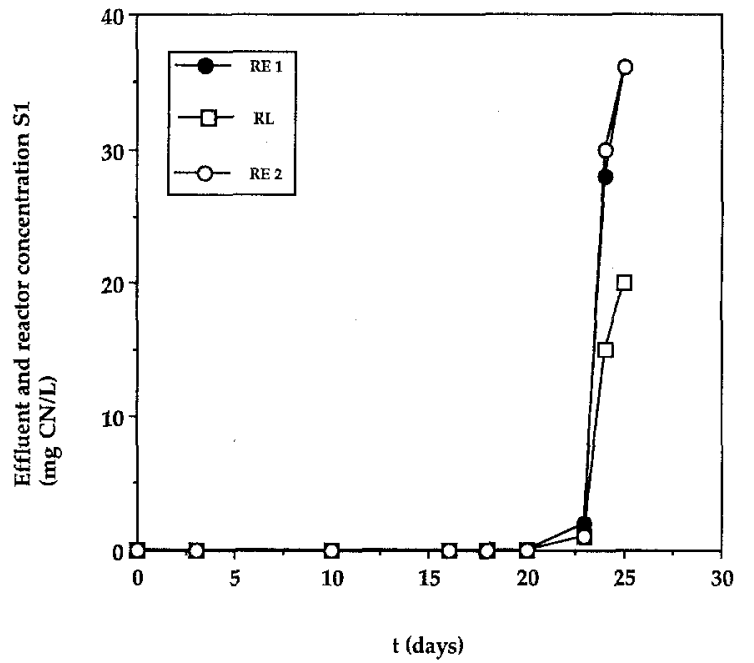

Fig. 8. Response of the reactor effluent concentrations during period II

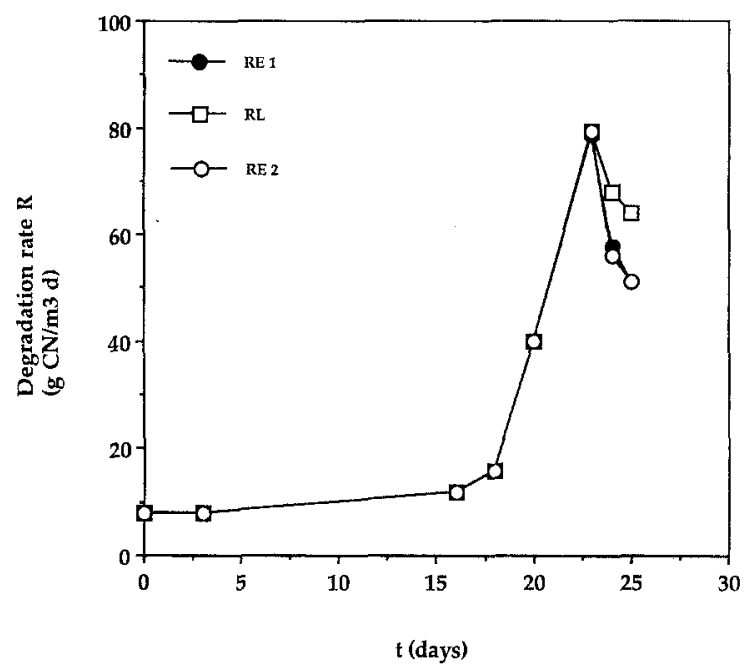

Fig. 9. Cyanide degradation rates of the three systems during period II. HRT $=24 \mathrm{~h}, \quad \mathrm{C}: \mathrm{N}: \mathrm{P}$ Ratio $=13: 1: 8.7$

and involved step increases in $\mathrm{CN}^{-}$loading as seen in Fig. 7. The response in the $\mathrm{CN}^{-}$effluent concentrations is seen in Fig. 8 . The $C: N: P$ ratio of the synthetic feed was $13: 1: 8.7$ and was kept constant during the entire period. The hydraulic retention time was $24 \mathrm{~h}$. After two weeks, the carriers in all reactors appeared to be covered with a biofilm.

The system with lactate as additional $C$-source had a particularly thick and dark microbial film. The biofilm of the two ethanol reactors were white. At the end of the startup phase at day 15, all three systems exhibited good cyanide and COD removal rates (Figs. 9 and 10). The cyanide consumption in RL was accompanied by an increase in ammonia. The other two reactors did not have any ammonia in the effluents nor did they have other degradation products, except traces of nitrate. However, the observed cyanide removal was correlated to the microbial COD removal.

To establish that cyanide transformation actually occurred in RE1 and RE2, investigations with altered feed composition were 


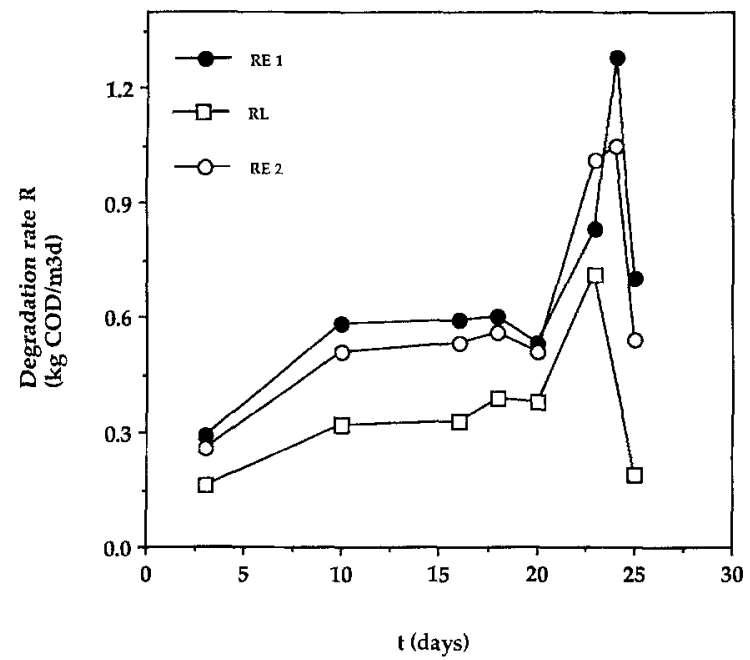

Fig. 10. COD degradation rates of the three systems during period II

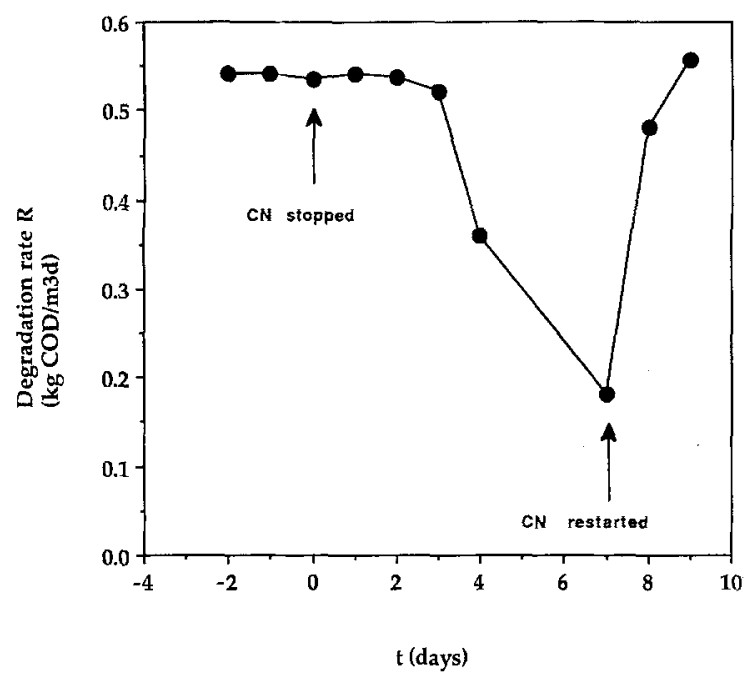

Fig. 11. Response of the reactor RE1 to the altered feed composition. COD loading $=0.66 \mathrm{~kg} / \mathrm{m}^{3} \mathrm{~d} ; \mathrm{S}_{0}=32 \mathrm{ppm} \mathrm{CN}$

made. In the absence of cyanide in the medium (no other $\mathrm{N}$ source) a dramatically decrease in COD degradation rates were observed (Fig. 11). Recovery occurred within two days after feeding cyanide again. The observed pattern of decline and recovery in COD removal, suggests that the utilization of COD depends on the presence of cyanide whose nitrogen metabolic products served as growth substrates for cyanide degrading bacteria.

\subsection{3}

\section{Oxygen uptake rate}

The influence of $\mathrm{CN}$ on the oxygen uptake rate (OUR) was determined off-line in a thermostated, stirred respirometer. The oxygen uptake rates were measured from a steady state reactor samples, having the following concentrations: $0.53 \mathrm{~kg} \mathrm{COD} / \mathrm{m}^{3}$ and $1 \mathrm{mg} \mathrm{CN} / \mathrm{m}^{3}$ for RE1, $0.23 \mathrm{~kg} \mathrm{COD} / \mathrm{m}^{3}$ and $0.5 \mathrm{mg} / \mathrm{m}^{3}$ for RL and $0.3 \mathrm{~kg} \mathrm{COD} / \mathrm{m}^{3}$ and $0.5 \mathrm{mg} \mathrm{CN} / \mathrm{m}^{3}$ for RE2. The reactor

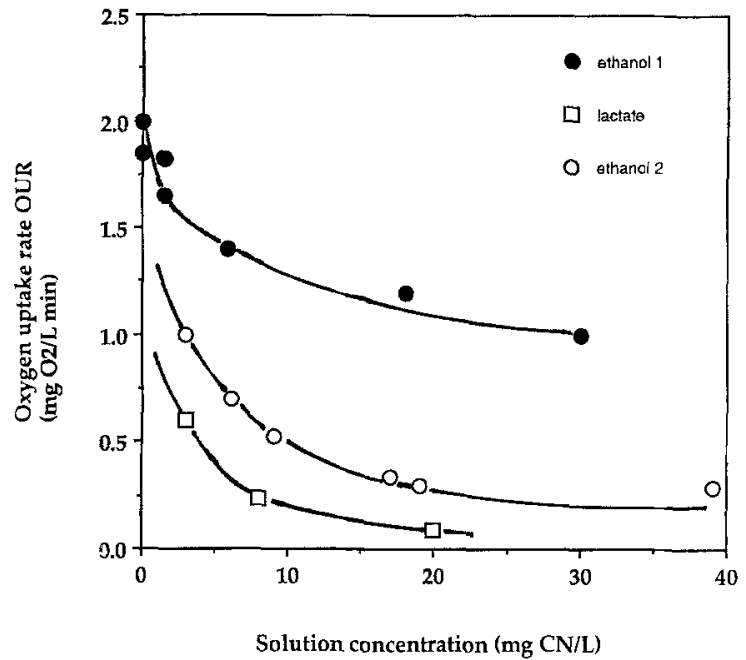

Fig. 12. Rate of oxygen uptake, in the presence of increasing concentrations of cyanide

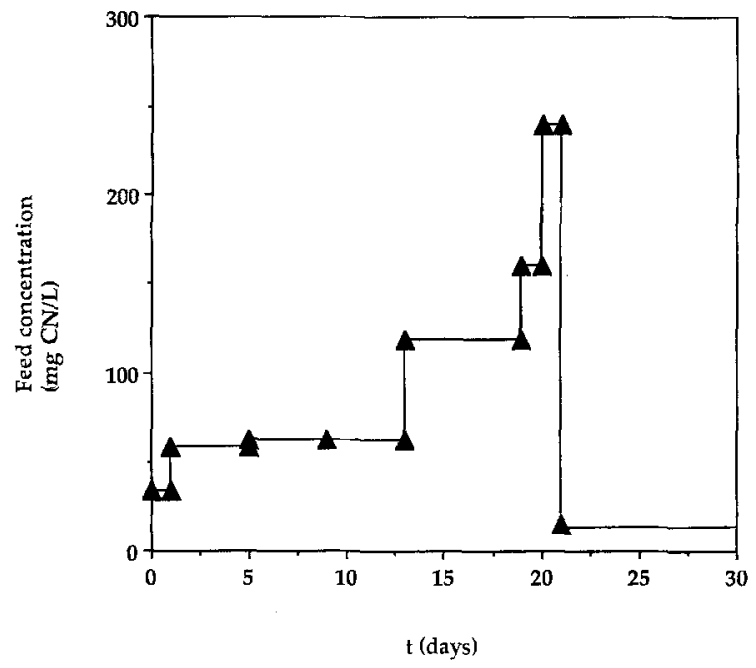

Fig. 13. Effluent concentration profile for period III

samples consisted of about $55 \mathrm{ml} \mathrm{liquid}$ and $5 \mathrm{ml}$ sand. After each measurement, $2 \mathrm{ml}$ of concentrated potassium cyanide solutions were injected into the respirometer. Typical results are shown in Fig. 12. The data show the highest oxygen uptake rate for RE1, followed by RE2 and RL. Experiments were made with increased COD, which indicated that COD was also limiting, but that the decrease in OUR, was due to $\mathrm{CN}$ inhibition.

\section{3}

\section{Period III}

\subsection{1}

\section{Optimisation experiments: Influence of $\mathrm{C} / \mathrm{N}$ ratio}

The requirements of nutrients for aerobic microorganisms have been well documented in the literature. Such ratios provide good guidelines for rough estimates. For example according to Grady and Lim [10], 0.066 grams of nitrogen are needed for each gram 
Table 3. Nitrogen balance during period III

\begin{tabular}{|c|c|c|c|c|c|c|}
\hline \multirow[t]{2}{*}{ Reactor } & \multirow[t]{2}{*}{ day } & \multicolumn{5}{|c|}{ Nitrogen balance } \\
\hline & & $\begin{array}{l}\mathrm{C}: \mathrm{N} \\
\text { ratio }\end{array}$ & $\begin{array}{l}\mathrm{N} \\
(\mathrm{CN}) \\
\text { feed } \\
\left(\mathrm{gN} / \mathrm{m}^{3}\right)\end{array}$ & 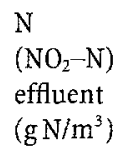 & $\begin{array}{l}\mathrm{N} \\
\left(\mathrm{NO}_{3}-\mathrm{N}\right) \\
\text { effluent } \\
\left(\mathrm{g} \mathrm{N} / \mathrm{m}^{3}\right)\end{array}$ & $\begin{array}{l}\mathrm{N} \\
\left(\mathrm{NH}_{4}-\mathrm{N}\right) \\
\text { effluent } \\
\left(\mathrm{g} \mathrm{N} / \mathrm{m}^{3}\right)\end{array}$ \\
\hline RE1 Ethanol & 1 & $13: 1$ & 17.23 & 2.1 & 10.3 & 0 \\
\hline RL Lactate & & & 17.78 & & & 6.5 \\
\hline RE2 Ethanol & & & 18.85 & 1.5 & 11 & 0 \\
\hline RE1 & 5 & $15: 1$ & 32.31 & 6.5 & 21.5 & 2 \\
\hline $\mathrm{RL}$ & & & 29.1 & & & 14 \\
\hline RE2 & & & 32.31 & 5 & 20 & 0 \\
\hline RE1 & 9 & $7.5: 1$ & 32.31 & 8 & 6 & 0 \\
\hline $\mathrm{RL}$ & & & 35 & & & 23 \\
\hline RE2 & & & 33.4 & 8 & 9 & 0 \\
\hline $\mathrm{RE} 1$ & 13 & $2.8: 1$ & 35.3 & 0 & 8 & 0 \\
\hline $\mathrm{RL}$ & & & 35.3 & & & 32 \\
\hline RE2 & & & 33.4 & 0 & 7 & 0 \\
\hline RL & 17 & $2.8: 1$ & 64 & & & 61 \\
\hline $\mathrm{RL}$ & 19 & $2.8: 1$ & 62.4 & & & 62 \\
\hline RL & 20 & $2.8: 1$ & 86 & & & 81.7 \\
\hline RL & 21 & $2.8: 1$ & 129 & & & 16 \\
\hline
\end{tabular}

Table 4. Cyanide balance during period III

\begin{tabular}{|c|c|c|c|c|c|c|c|}
\hline \multirow[t]{2}{*}{ Reactor } & \multirow[t]{2}{*}{ day } & \multicolumn{6}{|c|}{ Cyanide balance } \\
\hline & & $\begin{array}{l}\mathrm{C}: \mathrm{N} \\
\text { ratio }\end{array}$ & $\begin{array}{l}\text { Feed, } S_{0} \\
\left(\mathrm{~g} \mathrm{CN} / \mathrm{m}^{3}\right)\end{array}$ & $\begin{array}{l}\text { Loading rate, } L \\
\left(\mathrm{~g} \mathrm{CN} / \mathrm{m}^{3} \mathrm{~d}\right)\end{array}$ & $\begin{array}{l}\text { Effluent, } S_{1} \\
\left(\mathrm{~g} \mathrm{CN} / \mathrm{m}^{3}\right)\end{array}$ & $\begin{array}{l}\text { HCN stripped } \\
(\mathrm{gN} / \mathrm{d})\end{array}$ & $\begin{array}{l}\text { Degradation rate } R \\
\left(\mathrm{~g} \mathrm{CN} / \mathrm{m}^{3} \mathrm{~d}\right)\end{array}$ \\
\hline RE1 & 1 & $13: 1$ & 32 & 25.6 & 0.05 & 0 & 25.6 \\
\hline $\mathrm{RL}$ & & & 33 & 26.4 & 0.05 & 1.0 & 25.4 \\
\hline RE2 & & & 35 & 22.4 & 0.05 & 1.8 & 22.2 \\
\hline RE1 & 5 & $15: 1$ & 60 & 48 & 0.05 & 2.8 & 45.2 \\
\hline$R L$ & & & 54 & 43.2 & 4.0 & 4.1 & 39.1 \\
\hline RE2 & & & 60 & 48 & 5.0 & 5.1 & 43 \\
\hline RE1 & 9 & $7.5: 1$ & 60 & 48 & 25.0 & 3.5 & 24.5 \\
\hline $\mathrm{RL}$ & & & 65 & 52 & 0.04 & 1 & 51 \\
\hline RE2 & & & 62 & 50 & 23.0 & 4 & 27.2 \\
\hline RE1 & 13 & $2.8: 1$ & 65.5 & 52.4 & 42.5 & 4.1 & 14.3 \\
\hline $\mathrm{RL}$ & & & 65.5 & 52.4 & 0.05 & 0 & 52.4 \\
\hline RE2 & & & 62 & 50 & 40.05 & 2 & 15.6 \\
\hline$R L$ & 17 & $2.8: 1$ & 119 & 95.2 & 0.06 & 0 & 95.2 \\
\hline $\mathrm{RL}$ & 19 & $2.8: 1$ & 116 & 93 & 0.07 & 0 & 93 \\
\hline $\mathrm{RL}$ & 20 & $2.8: 1$ & 160 & 128 & 0.5 & 1.6 & 124 \\
\hline $\mathrm{RL}$ & 21 & $2.8: 1$ & 240 & 192 & 112 & 15 & 87 \\
\hline
\end{tabular}

carbohydrate $\left(\mathrm{CH}_{2} \mathrm{O}\right)$ removed. That gives a $\mathrm{C}: \mathrm{N}$ ratio of $6: 1$, and 1 grams of nitrogen is removed per 30 grams COD. After a steady-state condition was attained with $30 \mathrm{mg} \mathrm{CN}-1$ feed, the three reactors were operated under different $C: N$ ratios. From day 2 to day 13 the cyanide concentration in the feed was maintained at the same level while the carbon source was increased stepwise (Fig. 13). The results of these experiments of period III are summarized in Table 3 and 4 . The cyanide removal rate data are presented in Fig. 14. It seems that the specific molecule to be degraded, in this case the additional $\mathrm{C}$-source, plays a more important role than the simple $C: N$ ratio. For lactate as additive, the $\mathrm{C} / \mathrm{N}$ ratio did not seem to be significant at
$\mathrm{C} / \mathrm{N}$ values smaller than $10\left(50 \mathrm{~g} \mathrm{CN}^{-} / \mathrm{m}^{3} \mathrm{~d}\right)$. Only a slight decrease of the $\mathrm{CN}^{-}$degradation rates was observed at $\mathrm{C} / \mathrm{N}$ ratio $15\left(38 \mathrm{~g} \mathrm{CN} / \mathrm{m}^{3} \mathrm{~d}\right)$. For ethanol as additional $\mathrm{C}$-source, the influence of the $\mathrm{C}: \mathrm{N}$ ratio showed an opposite behaviour (Fig. 15). On day 14 the two reactors with ethanol were stopped because of increased cyanide concentration in the effluent (and reactor), as can be seen in Fig. 16. From day 13, the cyanide loading was further increased only for RL, stepwise until day 21 . The almost 100 percent utilization of the feed concentration of $0.160 \mathrm{~kg} \mathrm{CN}-1 \mathrm{~m}^{3}$, with a conversion rate of $0.124 \mathrm{~kg} \mathrm{CN}^{-} / \mathrm{m}^{3} \mathrm{~d}$, was observed in the reactor system with lactate as additive.

A subsequent increase of the feed concentration to 


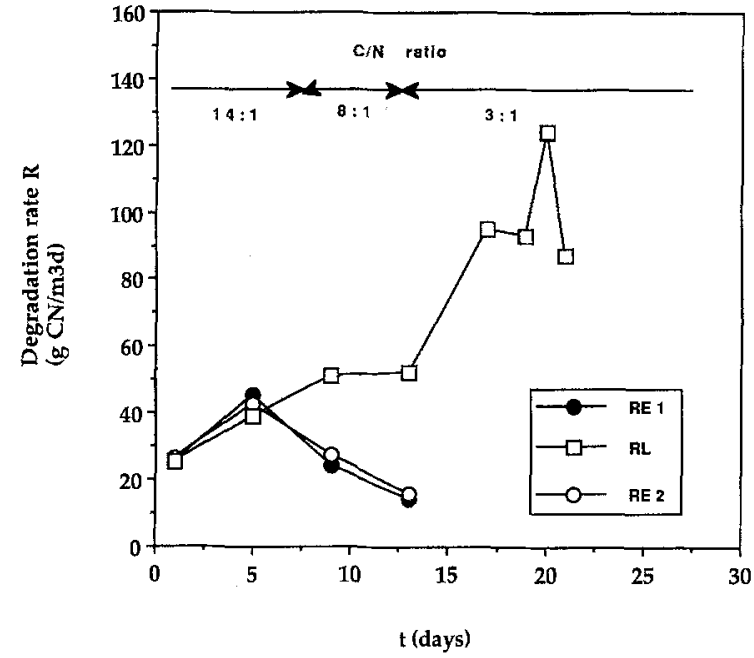

Fig. 14. Cyanide removal rates achieved with different $\mathrm{C} / \mathrm{N}$ feed ratios. $\mathrm{N}$ was varied with cyanide

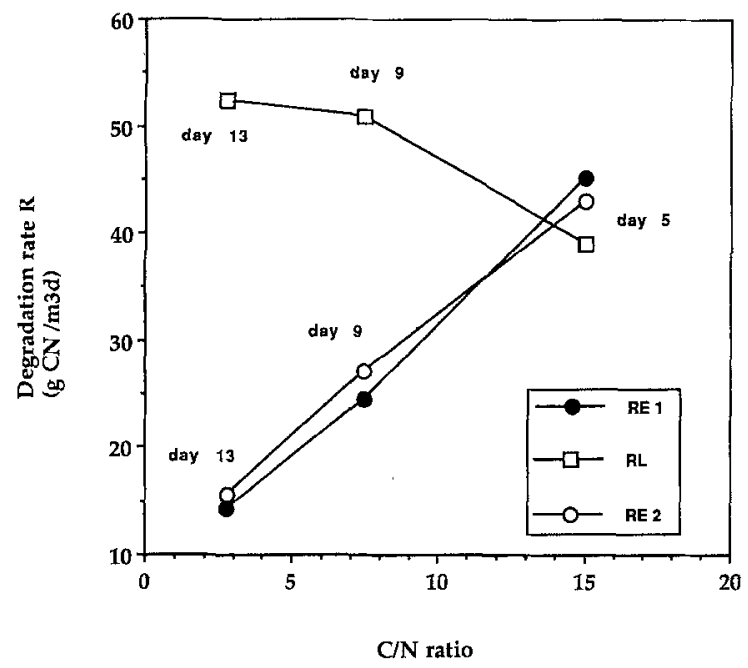

Fig. 15. Cyanide removal rates of the three systems operated at different $\mathrm{C} / \mathrm{N}$ ratios. $C$ was changed with carbon source

$0.240 \mathrm{~kg} \mathrm{CN}^{-} / \mathrm{m}^{3}$, resulted in a sharp increase in effluent concentration. The results in Table 3 , show an average bioconversion of $95 \%$ for lactate and approximately $60 \%$ for the ethanol systems. An observation from this study is that all systems responded to cyanide toxicity in the $1 \mathrm{mg} / \mathrm{l}$ range, as shown by the lactate system RL in Fig. 17, with a sharp loss of efficiency and a consequent severe increase in the effluent concentration. This sensitivity to low $\mathrm{CN}^{-}$concentrations would be important to any large-scale reactor operation.

\section{4}

\section{Period IV}

\subsection{1}

\section{Amygdalin: a cyanogenic glycoside}

One sand bed reactor was inoculated with sand and biomass from previous experiments and fed with amygdalin solution at

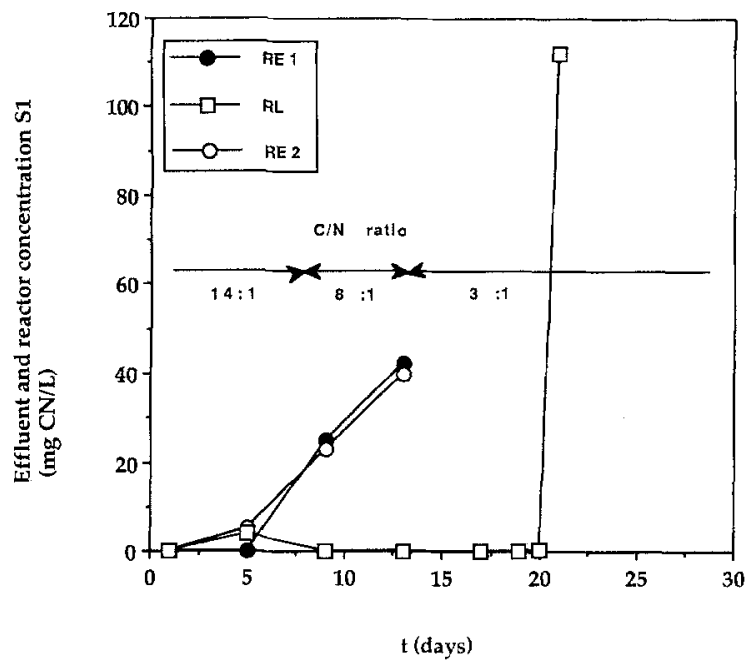

Fig. 16. Response of the three reactor effluent concentrations to loading periods at different $\mathrm{C} / \mathrm{N}$ ratios; $\mathrm{N}$ varied with cyanide

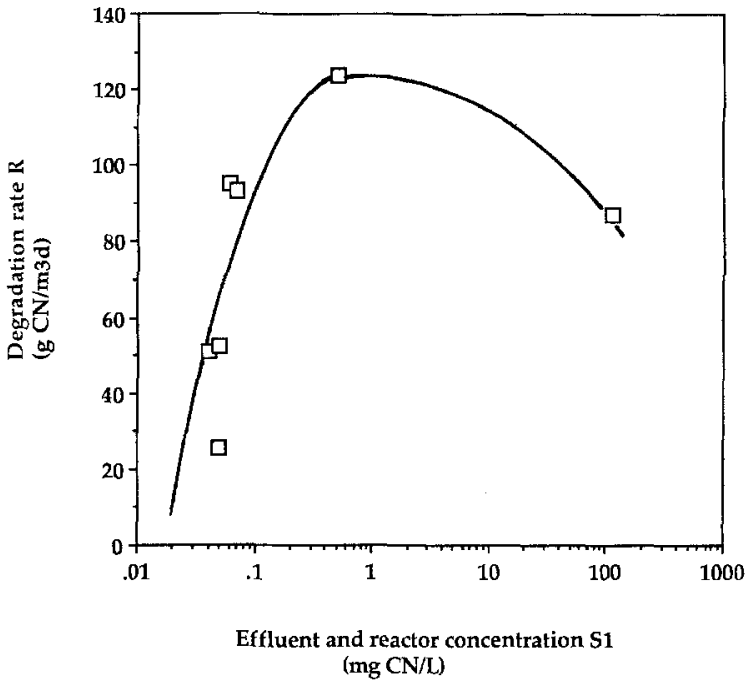

Fig. 17. Cyanide degradation rates of the lactate system versus reactor cyanide concentration during period III

various concentrations, supplemented with trace elements and a $0.005 \mathrm{~m}$ buffer solution at a residence time of $24 \mathrm{~h}$. After a few days a high COD degradation rate was obtained. The effluent samples were centrifuged at $5000 \mathrm{rpm}$ for $10 \mathrm{~min}$, and the COD analyses were made using a commercial colorimetric test system. The loads, as seen in Table 5, were $0.21,0.424,0.8$ and $1.2 \mathrm{~kg}$ amygdalin $/ \mathrm{m}^{3} \mathrm{~d}$. The lower the loading, the higher were the relative reductions. A maximum COD degradation rate of $1.2 \mathrm{~kg}$ $\mathrm{COD} / \mathrm{m}^{3} \mathrm{~d}$ was achieved during this period (Fig. 18) but was not the maximum possible rate. The degradation of amygdalin was estimated by the disappearance of ultraviolet (UV) absorbance. The measurements of the effluent were made at the wavelength $250 \mathrm{~nm}$, at which the expected degradation products have much higher molar extinction coefficients (amygdalin: mandelonitrile: benzaldehyde $=1: 6: 80$ ), as shown in Fig. 19. This disappearance of absorbance agreed with the percentage of COD degradation (Table 6) which was used to evaluate the performance of the 


\begin{tabular}{|c|c|c|c|c|c|c|c|}
\hline & $\begin{array}{l}\text { Period } \\
\text { (d) }\end{array}$ & $\begin{array}{l}\text { Loading } \\
\text { amygdalin } \\
\left(\mathrm{kg} / \mathrm{m}^{3} \mathrm{~d}\right)\end{array}$ & $\begin{array}{l}\text { Loading } \\
\text { COD } \\
\left(\mathrm{kg} / \mathrm{m}^{3} \mathrm{~d}\right)\end{array}$ & $\begin{array}{l}\text { Calculated } \\
\text { bound } \mathrm{CN}^{-} \\
\text {loading } \\
\left(\mathrm{g} / \mathrm{m}^{3} \mathrm{~d}\right)\end{array}$ & $\begin{array}{l}\text { Measured } \\
\text { bound } \mathrm{CN}^{-} \\
\text {loading } \\
\left(\mathrm{g} / \mathrm{m}^{3} \mathrm{~d}\right)\end{array}$ & $\begin{array}{l}\text { Influent } \\
\text { free } \mathrm{CN}^{-} \\
\left(\mathrm{g} / \mathrm{m}^{3}\right)\end{array}$ & $\begin{array}{l}\text { Resulting } \\
\mathrm{N} \\
\text { loading } \\
\left(\mathrm{g} / \mathrm{m}^{3} \mathrm{~d}\right)\end{array}$ \\
\hline & $1-4$ & 0.212 & 0.33 & 12 & 9 & $<0.01$ & 6.46 \\
\hline & $5-9$ & 0.424 & 0.66 & 24 & 22 & $<0.01$ & 12.9 \\
\hline & $10-13$ & 0.8 & 1.15 & 45.3 & 40 & $<0.01$ & 24.4 \\
\hline & $14-17$ & 1.2 & 1.69 & 68 & 62.4 & $<0.01$ & 36.58 \\
\hline
\end{tabular}

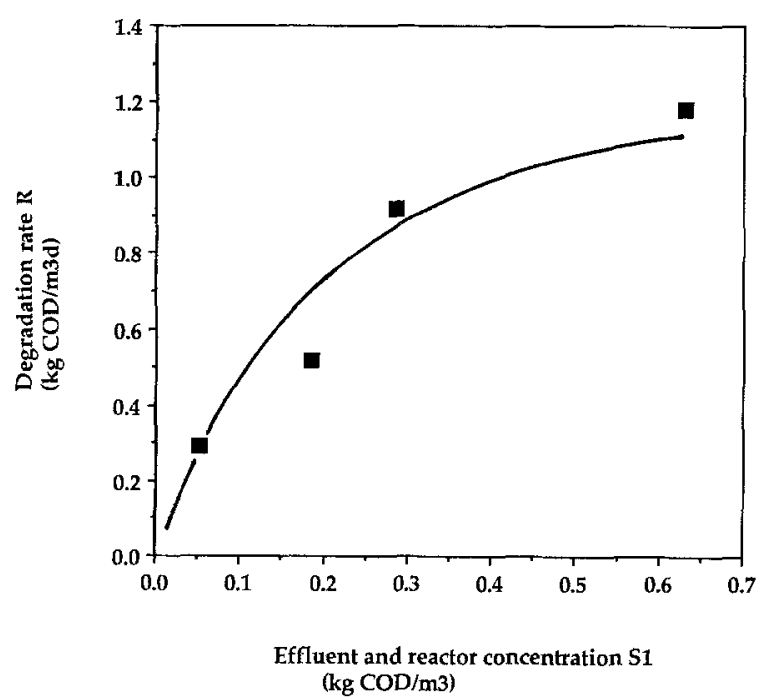

Fig. 18. COD degradation rates versus reactor COD reactor concentration of the system fed with amygdalin

Table 6. Degradation of amygdalin

\begin{tabular}{llll}
$\begin{array}{l}\text { Period } \\
\text { (d) }\end{array}$ & $\begin{array}{l}\text { Feed } \\
\left(\mathrm{kg} \mathrm{COD} / \mathrm{m}^{3}\right)\end{array}$ & $\begin{array}{l}\text { Degradation } \\
\text { measured as } \\
\text { COD removal } \\
(\%)\end{array}$ & $\begin{array}{l}\text { Degradation } \\
\text { based on photometric } \\
\text { analysis } \\
(\%)\end{array}$ \\
\hline $1-4$ & 0.413 & 87.4 & 84 \\
$5-9$ & 0.83 & 77.7 & 70.7 \\
$10-13$ & 1.44 & 80.2 & 61.8 \\
$14-17$ & 2.11 & 70.1 & 60 \\
\hline
\end{tabular}

reactor. No free cyanide, organically bound cyanide, ammonia, nitrate, nitrite and formamide could be detected in the effluent. Also the UV measurements precluded the presence of mandelonitrile and benzaldehyde, since these compounds have much higher molar extinction coefficients than amygdalin. Only traces of $\mathrm{HCN}$ could be detected in the exhaust gas. Therefore, it can be assumed, that the nitrogen degraded from amygdalin is mostly used in the fixed and free biomass, which increased visibly with increasing reactor loading. The average nitrogen content of the biomass constitutes 5-10 per cent. After day 17 of the amygdalin feeding period, the average value of biomass concentration was $2.35 \mathrm{~g}$ cell dry weight/l, which corresponds to approximately $85-223 \mathrm{mg}$ nitrogen accumulated in the biomass. Calculation of the total nitrogen fed during 17 days, from Table 5 , gives $200 \mathrm{mg}$ nitrogen, which corresponds approximately to the nitrogen content of the biomass.

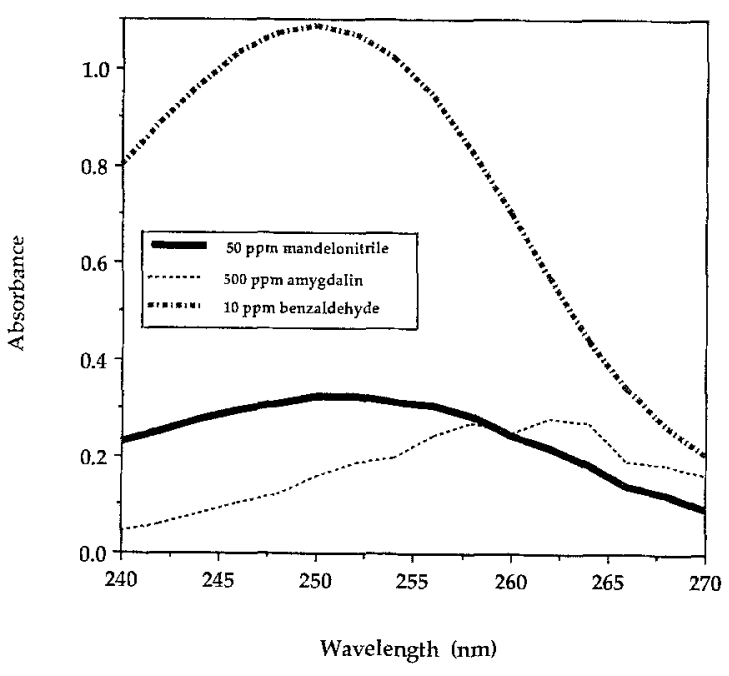

Fig. 19. UV absorption spectra of amygdalin, mandelonitrile and benzaldehyde in water; cuvette $=1 \mathrm{~cm}$

These experiments have shown that the principle cyanidecontaining compound from almond seeds can be completely degraded with respect to $\mathrm{COD}$ and $\mathrm{CN}^{-}$. An approximate nitrogen balance accounts for complete incorporation into the biomass.

\section{5 \\ Period V}

\subsection{1}

\section{Treatment of hot water extract of almond seeds}

Following the experiments with amygdalin, the degradation of hot water extract of almond seeds, as a simulated wastewater from the food processing industry, was investigated. In these experiments, five kilograms of almond seeds were extracted with 151 water. The seeds were stirred in a glass beaker for $4 \mathrm{~h}$ at $55^{\circ} \mathrm{C}$. After the extraction, the solution was cooled down to room temperature and divided in three parts. Two parts were filtered through a coarse filter. The third, unfiltered part was supplemented with buffer and trace elements solution. Only one of the filtered parts was supplemented with buffer and trace elements solution. The colloidal extract was then portioned and frozen. Every day a fresh portion was fed to the reactor, which operated at $24 \mathrm{~h}$ retention time and temperature of $35^{-} 37^{\circ}$. The feed was diluted to give various waste strengths from $1.9 \mathrm{~kg} \mathrm{COD} / \mathrm{m}^{3}$ to undiluted $5.5 \mathrm{~kg} \mathrm{COD} / \mathrm{m}^{3}$. As shown in Table 7 , the free $\mathrm{CN}^{-}$ content of the undiluted extract was between 13 and $16 \mathrm{ppm}$ and 
Table 7. Extract degradation

\begin{tabular}{|c|c|c|c|}
\hline Feed & $\begin{array}{l}\text { Influent } \\
\text { free } \mathrm{CN}^{-} \\
\left(\mathrm{g} / \mathrm{m}^{3}\right)\end{array}$ & $\begin{array}{l}\text { Influent } \\
\text { bound } \mathrm{CN}^{-} \\
\left(\mathrm{g} / \mathrm{m}^{3}\right)\end{array}$ & $\begin{array}{l}\text { Influent } \\
\text { COD } \\
\left(\mathrm{kg} / \mathrm{m}^{3}\right)\end{array}$ \\
\hline Feed not filtered & 15.8 & 7 & 5.9 \\
\hline Feed filtered and buffered & 13.2 & 8 & 5.6 \\
\hline Feed filtered & 13 & 8 & 5.14 \\
\hline
\end{tabular}

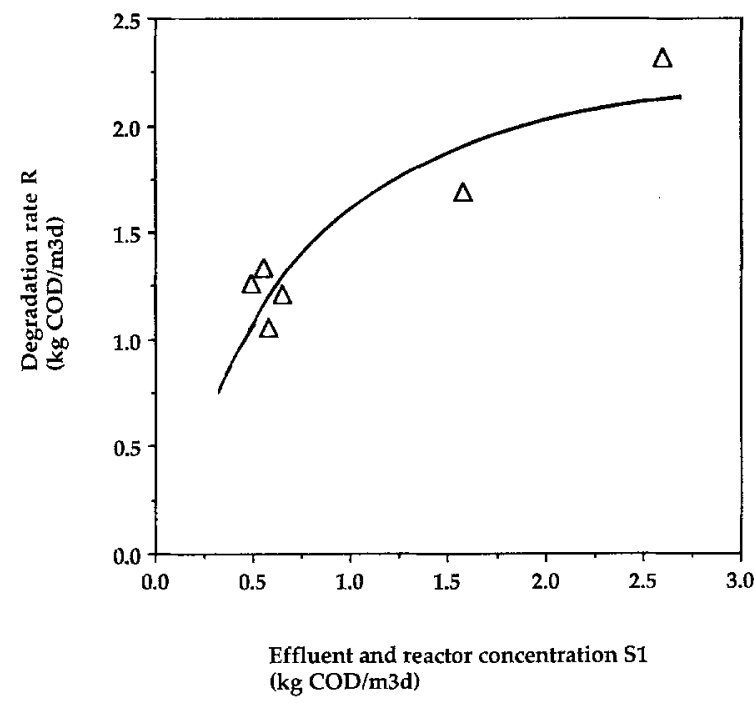

Fig. 20. COD degradation rates versus reactor and effluent COD concentration of the system fed with seed extract

the originally bound cyanide concentrations were $7^{-8} \mathrm{ppm}$. After two days of operation, a high biomass concentration was observed in the liquid phase and on the carrier, and high COD removal efficiencies $(53-70 \%)$, as seen in Fig. 20 , were obtained. At day 6 , the degradation rate became very high $\left(2.3 \mathrm{~kg} \mathrm{COD} / \mathrm{m}^{3}\right)$ and the oxygen transfer became critical. Therefore, loading was reduced by diluting the feed. During the entire period the effluent $\mathrm{CN}^{-}$concentration was below the detection limit (0.01 $\mathrm{mg} \mathrm{CN} \mathrm{CN}^{-} / 1$ with $10 \mathrm{~mm}$ cuvette). No differences in performance were found with buffered and supplemented feed.

These experiments demonstrated that actual wastewater from the almond seed processing could be degraded by adapted organisms and that cyanide did not present a problem. Higher rates could be achieved with higher oxygen transfer rates.

\section{4}

\section{Conclusions}

Degradation of cyanide as a nitrogen-source with various carbon sources was observed, using a mixed-culture adapted from soils.

At a hydraulic retention time of $24 \mathrm{~h}$ the system with lactate as the organic C-source was capable of operating at cyanide concentrations of $160 \mathrm{ppm} \mathrm{CN}^{-}$with a conversion rate of $0.125 \mathrm{~kg}$ cyanide $/ \mathrm{m}^{3} \mathrm{~d}$, having ammonia as nitrogen end product and an effluent concentration of $0.5 \mathrm{ppm} \mathrm{CN}^{-}$. The systems with ethanol as the organic C-source could degrade at a rate of $0.05 \mathrm{~kg}$ cyanide $/ \mathrm{m}^{3} \mathrm{~d}$ using a feed concentration of $60 \mathrm{ppm}$ cyanide. Both systems were able to overcome short-time shockloading. No growth and no cyanide degradation was found in the system with cyanide as the sole source of carbon and nitrogen.

The stripping effect, during the treatment in an aerobic fluidized bed reactor in which cyanide is removed, can be considered to be very small, because of the very low cyanide concentration maintained in the reactor. The upper concentration limit for effective aerobic degradation was found to be around two ppm cyanide.

The $\mathrm{C} / \mathrm{N}$ ratio of the feed did not seem to be a significant factor.

While feeding amygdalin as an organic cyanide precursor, degradation rates up to $1.2 \mathrm{~kg} \mathrm{COD} / \mathrm{m}^{3} \mathrm{~d}$ were measured with no free or organically bound cyanide in the effluent. Nitrate, nitrite, formamide and ammonia were not found as a result of $\mathrm{CN}^{-}$ transformation, but a thick and dark microbial film could be observed, enough to account for the overall nitrogen consumption.

The experiments with almond seed extract, confirmed the applicability of the aerobic process to treat food processing industry streams containing cyanide with high COD amounts.

This work demonstrates that the biological treatment in a fluidized bed reactor is a convenient method to treat food industry streams containing dilute cyanide, free or organically bound. However, the data collected from this investigation shows, that there are limiting factors such as the oxygen transfer rate and the high biomass growth. An anaerobic reactor would possibly offer a better process for treating these wastewaters.

\section{References}

1. Huiatt, J. La: Cyanide from mineral processing: Problems and research needs. Proc. of the conference: Cyanide and the environment. Tucson, Arizona. vol. 1, pp. 65-81 (December 1984)

2. Knowles, C. J.: Cyanide utilization and degradation by microorganisms. Cyanide compounds in biology, Wiley, Chichester (Ciba Foundation Symposium 140) pp. 3-15 (1988)

3. Fry, W. E.; Millar, R. L.: Cyanide degradation by enzyme from Stemphylium loti. Arch. Biochem. Biophys. 151 (1972) 468-474

4. Basheer, S.; Kut, Ö, M.; Prenosil, J. E.; Bourne, J. R.: Kinetics of enzymatic degradation of cyanide. Biotechnol. Bioeng. 39 (1992) 629-634

5. White, J. M.; Jones, D. D.; Huang, D.; Gauthier, J. J.: Conversion of cyanide to formate and ammonia by a pseudomonad obtained from industrial wastewater. J. Ind. Microbiol. 3 (1988) 263-272

6. Richards, J. D.; Shieh, K. W.: Anoxic-oxic activated-sludge treatment of cyanides and phenols. Biotechnol. Bioeng. 33 (1989) 32-38

7. Nutt, S. G.; Melcer, H.; Pries, J. H.: Two-stage biological fluidized bed treatment of coke plant wastewater for nitrogen control. J. Water Pollut. Control Fed. 56 (1984) 851-857

8. Melcer, H.; Nutt, S. G.; Marvan, I.; Sutton, P.: Combined treatment of coke plant wastewater and blast furnace blowdown water in a coupled biological fluidized bed system. J. Water Pollut. Control Fed. 56 (1984) 192-198

9. Fallon, R. D.; Cooper, D. A.; Speece, R.; Henson, M.: Anaerobic biodegradation of cyanide under methanogenic conditions. Appl. Environ. Microbiol. 1656-1662 (June 1991)

10. Grady, C. P.; Lim, H. C.: Biological wastewater treatment. Pollut. Eng. Technol. 12 (1980) 270-302 